\title{
The Profile and Determinant Factors of Quality of Life in Patients with Diabetic Neuropathy
}

\author{
Profil dan Faktor Determinan Kualitas Hidup pada Pasien Neuropati \\ Diabetika
}

Rizaldy Taslim Pinzon, Kadek Sinthia Grahita Adnyana, Marta Lisnawati Zalukhu

Faculty of Medicine Duta Wacana Christian University, Yogyakarta, Indonesia

\begin{abstract}
Neuropathy is one of the most common complications in patients with diabetes mellitus (DM). Neuropathy has contributed to some impacts of quality of life (QOL), general health status, and socio-economy level. Therefore, it is important to understand more about this issue, so appropriate treatment could be taken to improve QOL of patients with diabetic neuropathy. This study aimed to measure the profile of a patient's life quality in DM with neuropathy. This study was a observational study using Short Form 8 (SF-8) Health Survey Standard Indonesia to measure the QOL in patients with diabetic neuropathy that were treated consecutively from March to August 2016 in the Department of Neurology in Bethesda Hospital, Yogyakarta. By 57 patients with diabetic neuropathy were enrolled as subjects in this study. Most of them were women (52,6\%). The mean age of subjects was $57.3 \pm 5.85$ years. The lowest QOL score in patients with diabetic neuropathy were observed in general health perceptions category (45.26\%), followed by bodily pain (57.19\%), vitality or energy (69.12\%), physical functioning $(69.82 \%)$, social role functioning $(74.03 \%)$, mental health $(78.59 \%)$, physical role functioning $(80.70 \%)$, and emotional role functioning (81.05\%). Patients with diabetic neuropathy have poor QOL. Sex and age were not significantly related to the QOL in patients with diabetic neuropathy.

Keywords: Diabetic neuropathy, quality of life, Short Form 8 Health Survey
\end{abstract}

\begin{abstract}
Neuropati merupakan salah satu komplikasi tersering pada diabetes melitus (DM). Neuropati dapat memengaruhi kualitas hidup, derajat kesehatan, maupun tingkat ekonomi. Oleh karena itu, penting untuk mengetahui kualitas hidup pasien DM dengan neuropati beserta dampak yang ditimbulkannya terlebih dahulu agar mendapatkan penanganan yang tepat demi meningkatkan kualitas hidup pasien. Penelitian ini bertujuan untuk mengetahui profil kualitas hidup pasien DM dengan neuropati. Penelitian ini merupakan studi observasional menggunakan Short Form 8 (SF-8) Health Survey Standard Indonesia terhadap pasien diabetes melitus dengan neuropati yang diambil secara konsekutif pada bulan Maret hingga Agustus 2016 di Poli Saraf Rumah Sakit Bethesda, Yogyakarta. Terdapat 57 subjek yang dimasukkan dalam penelitian ini. Sebanyak 52,6\% di antaranya adalah perempuan dengan rerata usia 57,3 $\pm 5,85$ tahun. Skor kualitas hidup pasien neuropati DM yang paling rendah terdapat pada kategori kesehatan umum $(45,26 \%)$ disusul nyeri pada tubuh $(57,19 \%)$, vitalitas atau energi $(69,12 \%)$, fungsi fisik $(69,82 \%)$, fungsi sosial $(74,03 \%)$, kesehatan mental $(78,59 \%)$, kemampuan peran dengan masalah kesehatan fisik $(80,70 \%)$, dan kemampuan peran dengan masalah emosi $(81,05 \%)$. Jenis kelamin dan usia tidak berhubungan secara signifikan terhadap kualitas hidup pasien DM dengan neuropati.
\end{abstract}

Kata Kunci: Neuropati diabetika, kualitas hidup, Short Form 8 Health Survey

How to Cite: Pinzon RT, Adnyana KSG, Zalukhu ML. The profile and determinant factors of quality of life in patients with diabetic neuropathy. Kesmas: National Public Health Journal. 2017; 12(1): 38-42. (doi:10.21109/kesmas. v11i4.1252)

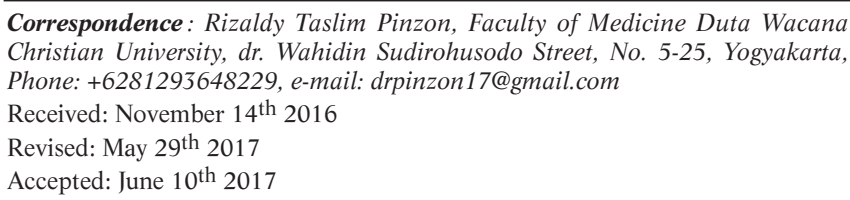

Correspondence: Rizaldy Taslim Pinzon, Faculty of Medicine Duta Wacana Christian University, dr. Wahidin Sudirohusodo Street, No. 5-25, Yogyakarta, Phone: +6281293648229, e-mail: drpinzon17@gmail.com

Received: November $14^{\text {th }} 2016$

Revised: May 29th 2017

Accepted: June $10^{\text {th }} 2017$ 


\section{Introduction}

Diabetes mellitus (DM) is one of the most common chronic non-infectious diseases and the one of the leading public health problems in modern society. ${ }^{1}$ Patients with DM currently reach 380 million people worldwide and this number will increase to 593 million in 2035. Patients diagnosed with DM in Indonesia until 2013 was $6.9 \%$, or about 12 million people. The prevalence of DM complications also reportedly increased. ${ }^{2}$ Late complications of DM associated with high number of morbidity and mortality caused by primary disease effect or secondary complications. ${ }^{3}$ Proportion of patients with DM also increases with age, and most common in women. ${ }^{4}$ The incidence of DM also increased twice in the last third decades of life and have a big impact on quality of life (QOL), health status and economic levels.

Neuropathy is one of common complications in patients with type 1 and type 2 of DM. ${ }^{2}$ Diabetic neuropathy is the presence of symptoms or signs of peripheral nerve dysfunction of diabetic patients. ${ }^{5}$ Neuropathy can be in many types, both focal and symmetrical type. The most common forms are chronic, symmetrical, and length-dependent axonal sensory-motor poly-neuropathy. Most patients experience sensory symptoms either positive or negative symptoms, but some others apparently asymptomatic. The symptoms can fluctuate over time. Some of them experience pain associated with neuropathy. There are also known as painful diabetic neuropathy (PDN), which has strong ties with the other complications of diabetes. ${ }^{1,6}$

PDN is the most common cause of neuropathic pain that can be clinically diagnosed. Symptoms are felt mostly in the area of the distal and symmetric (glove and stocking pattern), associated with exacerbations at night, and described as stabbed pain, electrical sensation, tenderness, and burning with hyperalgesia and allodynia during the examination. PDN also makes wider impact on other aspects such as sleep disturbance, mood, mental status, and daily living activities that have negative effects on QOL, especially in physical function, decrease of QOL over time, and improve health financing long term. ${ }^{1,6-7}$

There are some instruments that can be used to assess the QOL in patients with PDN such as the Short Form
(36) Health Survey or SF-36, SF-12, EQ-5D, and also SF8. Another instrument that identifies QOL associated PDN specifically include PN-QOL-97, Norfolk QOL-DN, and NeuroQol. ${ }^{8}$ The SF-8 was developed to replicate the SF-36 with one question for each health domain. It covers some points about general health perceptions, physical functioning, physical role functioning, bodily pain, vitality (energy), social role functioning, mental health, and emotional role functioning. SF-8 is proved to be reliable and valid in assessing the general physical health and mental health at population. ${ }^{9}$ The presence and severity of neuropathic pain associated with degradation of the QOL that can also give an impact on escalation of health financing in long-term. The aim of this study was to measure the QOL of diabetic patients with neuropathy and the impact of neuropathy.

\section{Method}

This study was an observational study using cross-sectional analytic design. DM patients with neuropathy who were treated consecutively from March to August 2016 in Department Neurology of Bethesda Hospital, Yogyakarta became the subject for this study. The inclusion criteria were patients with DM with signs and symptoms of peripheral neuropathy, do not have a history of severe mental illness, aged 18-65 years old, and willing to participate in study.

The assessment of QOL in diabetic patients with neuropathy had used the SF-8 Health Survey Standard Indonesia. SF-8 includes eight questions that each item is intended to evaluate the QOL of diabetic patients with neuropathy. The use of SF- 8 is based on the previous studies that show this brief questionaire is comparable with SF-12 and SF-36. The brief questionnaire is advantage in practical. ${ }^{10-11}$ The data are processed through descriptive analysis and statistical computerized. Statistical analysis includes a multivariate analysis of variance (MANOVA) to identifying determinant factors of QOL in patients with diabetic neuropathy.

\section{Results}

The study involved 57 subjects who were qualified for eligibility criteria. Table 2 shows female subjects were $30(52.6 \%)$ and men were $27(47.4 \%)$. The highest age

Table 1. SF 8 Health Survey Standard

\begin{tabular}{ll}
\hline Domain of SF 8 Health Survey Standard & \multicolumn{1}{c}{ Answer Choices } \\
\hline $\begin{array}{l}\text { General health perceptions } \\
\text { Physical functioning }\end{array}$ & Excellent/Very Good/Good/Fair/Poor/Very poor \\
$\begin{array}{l}\text { Physical role functioning } \\
\text { Bodily pain }\end{array}$ & Not at all/Very little/Somewhat/Quite a lot/Could not do physical activities \\
Vitality (energy) & Not at all/Very little/Somewhat/Quite a lot/Could not do daily work \\
Social role functioning & None/Very mild/Mild/Moderate/Severe/Very severe \\
Mental health & Very much/Quite a lot/Some/A little/None \\
Emotional role functioning & Not at all/Very little/Somewhat/Quite a lot/Could not do social activities \\
& Not at all/Slightly/Moderately/Quite a lot/Extremely \\
& Not at all/Very little/Somewhat/Quite a lot/Could not do daily activities \\
\hline
\end{tabular}


range 61-65 years $(35.1 \%)$. The QOL in women was slightly lower than men (Figure 1). In addition, the youngest age range (41-45 years) had a better QOL than other age ranges (Figure 2). Overall, statistical analysis showed that there was no significant difference between sex and age on the QOL of diabetic patients with neuropathy.

\section{Discussion}

This study showed that sex did not have a significant relation statistically with QOL of diabetic neuropathy patients, even though the much higher proportion of females than males with diabetic neuropathy symptoms was shown by previous study ( $p$ value $<0.0001$ ). ${ }^{12}$ Demographic factors and the patients' records have a negative impact on QOL among low education levels, lack of employment, uncontrolled diabetes, and use of therapeutic insulin. ${ }^{13}$

Based on age, duration of diabetes and neuropathy clinical differences showed that women still had 50\% greater risk of experiencing more severe symptoms of neuropathy than men. ${ }^{12}$ It is also compatible with this study, the percentage of the average number on QOL of women with DM neuropathy was lower than men, but not statistically significant. Previous study found that women with diabetes had greater prevalence of occurrence for neuropathic pain. Pain and neuropathy are two factors that significantly bring negative impact on QOL.
Previous study presented that demographic data and medical history, such as low education levels, lack of employment, uncontrolled diabetes, and the use of insulin therapy also had negative impact on the QOL of people. Thus, it is important to be evaluated more. ${ }^{13,14}$

Earlier studies showed that the risk factors of neuropathic pain in diabetes was higher in elderly, low of socioeconomic status, insulin therapy using, long duration of diabetes and bad glycemic control. ${ }^{15}$ Average age who had diabetes with neuropathy in this study was $57.3 \pm$ 5.85 years, which is almost the same as the average age in the earlier study ( $57.2 \pm 5.85$ years). ${ }^{16}$ Socio-economic status, duration of diabetes, history of the use of insulin and glycemic control in this study were not evaluated.

General health status had the lowest percentage of

Table 2. Basic Characteristics of Patients with Diabetic Neuropathy, Mean of SF8 Score and the Result of Multivariate Analysis

\begin{tabular}{crrr}
\hline Characteristic & n (\%) & Mean of SF-8 Score & p value \\
\hline Sex & & $27.79 \pm 4.61(69.47 \%)$ & 0.361 \\
Women & $30(52.6 \%)$ & $27.40 \pm 3.17(68.5 \%)$ & \\
Men & $27(47.4 \%)$ & $28.22 \pm 5.85(70.55 \%)$ & \\
Age (years) & & & \\
$41-45$ & $3(5.3 \%)$ & $30.67 \pm 2.31(76.67 \%)$ & 0.539 \\
$46-50$ & $4(7 \%)$ & $28.00 \pm 2.16(70 \%)$ & 1.000 \\
$51-55$ & $12(21.1 \%)$ & $26.92 \pm 3.23(67.3 \%)$ & 0.765 \\
$56-60$ & $16(28.1 \%)$ & $27.00 \pm 4.24(67.5 \%)$ & 0.779 \\
$61-65$ & $20(35.1 \%)$ & $28.45 \pm 6.05(71.12 \%)$ & 0.898 \\
$66-70$ & $2(3.5 \%)$ & $28.00 \pm 5.66(70 \%)$ & - \\
Mean of age $=57.3 \pm 5.85$ year & & \\
\hline \multicolumn{4}{r}{} \\
\hline
\end{tabular}

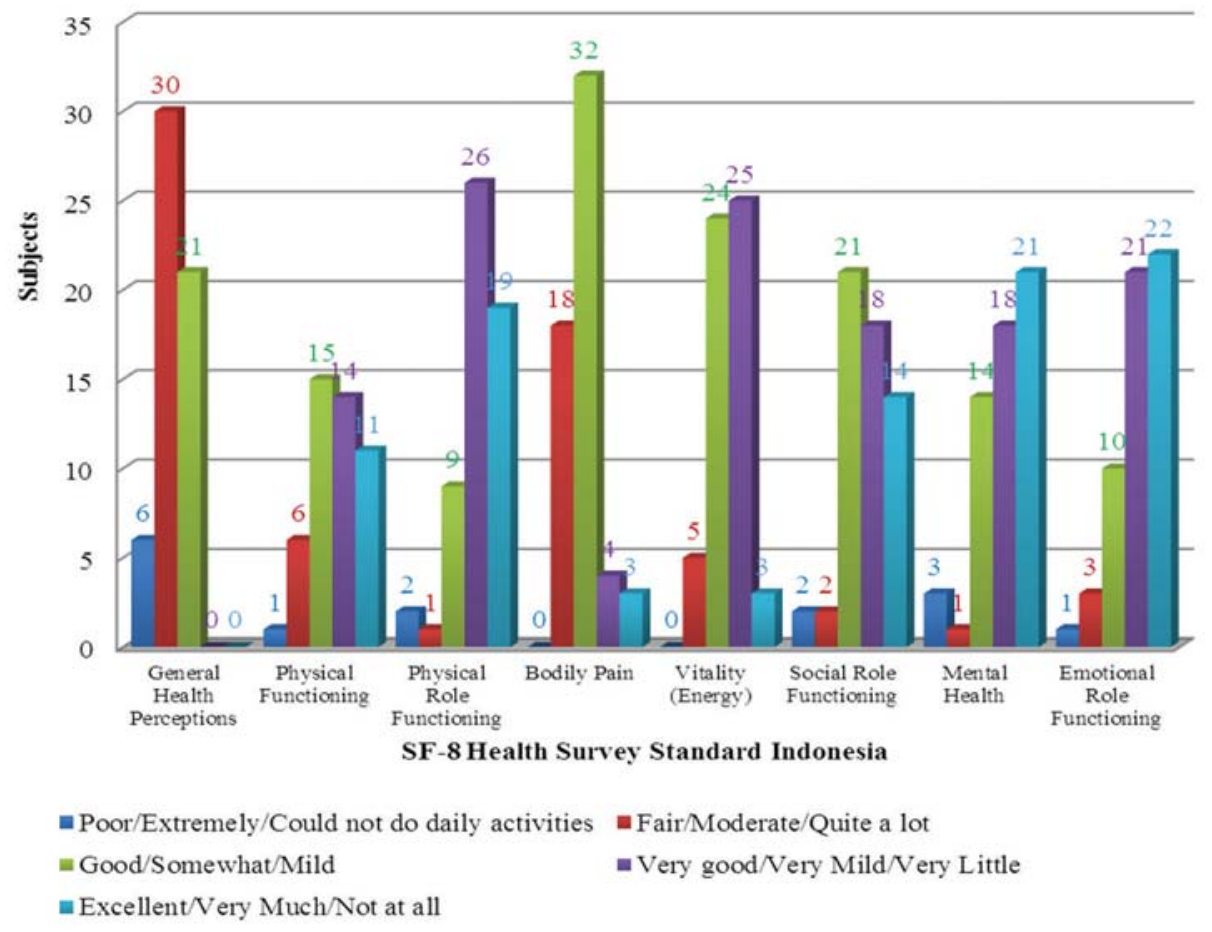

Figure 1. Profile of Quality of Life in Patients with Diabetic Neuropathy Based on SF-8 Health Survey Standard Indonesia 


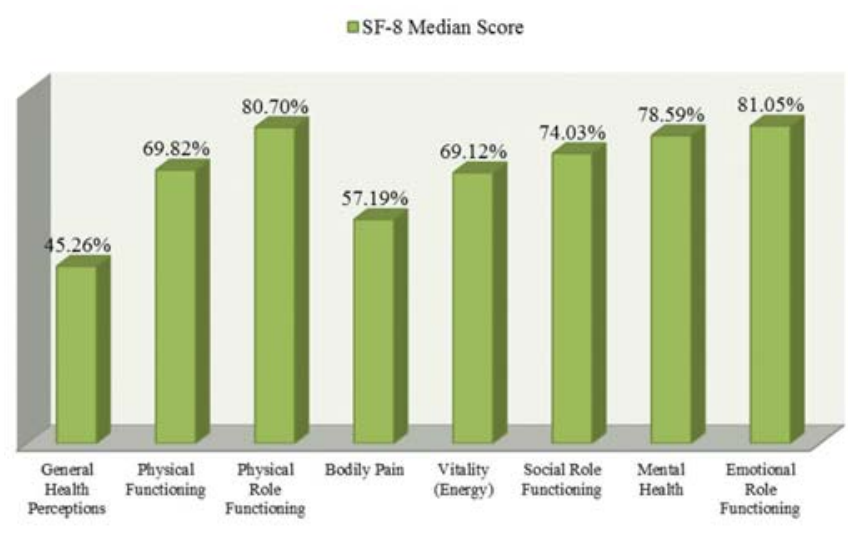

Figure 2. General Profile of Quality of Life in Patient with Diabetic Neuropathy

QOL in this study. Subjects assumed that their health was quite disturbed by the presence of neuropathy. Complications and comorbidities significantly decreased QOL. Previous study showed hypertension disease as the most chronic complication that had been frequently appeared on elderly with DM. QOL of diabetic neuropathy patients correlated with underlying disease state or comorbidities, such as hypertension and dyslipidemia that may interfere patients' ability function especially general health status and patient's QOL in general. ${ }^{13,17,18}$

Bodily pain is the second most impact to QOL in patients with diabetic neuropathy in this study. PDN is one form of diabetes neuropathy that affects $16-34 \%$ of patients with diabetes. Experience of pain did not only become a burden on the patient, but also become a secondary cause of disability due to the occurrence of sleep disorders, mood disorders such as anxiety, and impaired of physical function. ${ }^{19}$ Previous study also showed that the QOL of diabetic patients with neuropathic pain was worse than the group without pain. The manifestations of neuropathic pain associated with chronic back pain potentially more intrusive than the DM disease themselves. ${ }^{1}$

Diabetes is associated with low physical function. It was caused by peripheral nerve dysfunction. The presence of diabetes also accelerates the loss of muscle function and muscle protein synthesis as well as peripheral nerve dysfunction which decreases mass and muscle strength. It also influences the occurrence of limitations physical activity. ${ }^{20}$ In this study, the same results were shown by physical function, followed by vitality/energy, but physical role functioning was still in good range. Good result from physical role functioning still need to be further evaluated and compared to other factors, such as duration of diabetes and the degree of neuropathic pain because both of these also influence the various categories assessed in determining patients' QOL. ${ }^{14}$

Neuropathic pain in diabetic patients have a role to impaired functioning and mental health status because it requires more time, energy and costs to get therapy. The bad quality of mental health status in diabetic patients with neuropathy also makes big impact to patients' QOL generally. The prior study reported that patients of diabetes with neuropathic pain actually had high levels of depression, anxiety, and sleep disorders that were more frequent than neuropathy without pain. The intensity of pain and more severe intensity of depression are associated with low-income QOL. ${ }^{1}$ In this study, social function, mental health, and the ability roles with emotional problems had higher percentage of QOL than other categories. It still needs to be studied further related to the yield difference between the QOL of patients with DM neuropathy pain and without pain.

Based on the SF-8 Health Survey Standard Indonesia Score, patients with diabetic neuropathy in this study showed poor QOL in general health perceptions, bodily pain, vitality (energy) and physical functioning, while other category were still in good range. The QOL in diabetic patients is one of the most important aspects related to life impacts, long-term prognosis, and the economic burden of the consequences. Therefore, it is necessary to evaluate more about the symptoms and causes of general health perceptions, physical functioning, physical role functioning, bodily pain, vitality (energy), social role functioning, mental health, and emotional role functioning issues for more appropriate management to improve health and QOL in patients with diabetic neuropathy.

\section{Conclusion}

Neuropathy in diabetic patients impairs their QOL. In this study, the lowest QOL is shown by general health perceptions, followed by bodily pain, vitality or energy and physical functioning. Sex and age do not significantly relate to the QOL in patients with diabetic neuropathy. Further studies including a larger sample size should be carried out to assess significant impact on QOL in diabetic patients with neuropathy and effective management of such impact.

\section{References}

1. Dobrota VD, Hrabac P, Skegro D, Smiljanic R, Dobrota S, Prkacin I, et al. The impact of neuropathic pain and other comorbidities on the QOL in patients with diabetes. Health and QOL Outcomes. 2014; 12: 171.

2. International Diabetes Federation. IDF Diabetes Atlas. $6^{\text {th }}$ ed. 2013 [cited 2016 Sept 23]. Available from: www.diabetesatlas.org.

3. Rajan RS, de Gray L, George E. Painful diabetic neuropathy. Continuing education in anaesthesia, critical care and pain. Revalidation for Anaesthetists. 2013; 14: 230-5.

4. Kementrian Kesehatan Republik Indonesia. INFODATIN. Pusat Data dan Informasi Kementerian Kesehatan Republik Indonesia. Situasi dan Analisis Diabetes. 2014 [cited 2016 Sept 26]. Available from: http://www.depkes.go.id

5. Bansal V, Kalita J, Misra UK. Diabetic neuropathy. Postgraduate Medical Journal. 2006; 82: 95-100. 
6. Kulkantrakom K, Lorsuwansiri C. Sensory profile and its impact on QOL in patients with painful diabetic polyneuropathy. Journal of the Neurological Sciences. 2013; 333(496): 519-36.

7. Tsuji M, Yasuda T, Kaneto H, Matsuoka T, Hirose T, Kawamori R. Painful diabetic neuropathy in Japanese diabetic patients is common but underrecognized. Pain Study and Treatment. 2013; 2013 : 318352.

8. Smith SC, Lamping DL, Maclaine GDH. Measuring health-related QOL in diabetic peripheral neuropath: a systematic review. Diabetes Study and Clinical Practice. 2012; 96: 261-70.

9. Roberts B, Browne J, Ocaka KF, Oyok T, Sondorp E. The realibility and validity of the SF-8 with a conflict-affected population in northern Uganda. Health and QOL Outcomes. 2008; 6:108.

10. Lefante JF, Harmon GN, Ashby KM, Bernard D, Webber LS. Use of the SF-8 to assess health related QOL for a chronically ill, low income population participating in the Central Louisiana Medication Assess Program (CMAP). QOL Study. 2005; 14: 665-73

11. Tokuda Y, Okubo T, Ohde S, Jacobs J, Takahashi O, Omata F, et al. Assessing items on the SF-8 Japanese version for health-related QOL: a psychometric analysis based on the nominal categories model of item response theory. Value in Health. 2009; 12(4): 569-73.

12. Abbott CA, Malik RA, van Ross E, Kulkarni J, Boulton AJM. Prevalence and characteristics of painful diabetic neuropathy in a large comunitybased diabetic population in the UK. Diabetes Care. 2011; 34: 2220-4.

13. Cheah WL, Lee PY, Lim PY, Fatin Nabila AA, Luk KJ, Nur Irwana AT.
Perception of QOL among people with diabetes. Malaysian Family Physician. 2012; 7(2\&3): 21-30.

14. Davies M, Brophy S, Williams R, Taylor A. The prevalence, severity, and impact of painful diabetic peripheral neuropathy in type 2 diabetes. Diabetes Care. 2006; 29(7): 1518-22.

15. Morkrid K, Ali L, Hussain A. Risk factors and prevalence of diabetic peripheral neuropathy: a study of type 2 diabetic outpatients in Bangladesh. International Journal of Diabetes in Developing Countries. 2010; 30(1): 11-7.

16. Boru UT, Alp R, Sargin H, Kocer A, Sargin M, Luleci A, et al. Prevalence of peripheral neuropathy in type 2 diabetic patients attending a diabetes center in Turkey. Endocrine Journal. 2004; 51(4): 563-7.

17. Rosyada A, Trihandini I. Determinan of DM chronic complications on elderly. Kesmas: National Public Health Journal. 2013; 7(9): 395-401.

18. Boyd A, Casselini C, Vinik E, Vinik A. QOL and objective measures of diabetic neuropathy in a prospective placebo-controlled trial of ruboxistaurin and topiramate. Journal of Diabetes Science and Technology. 2011; 5(3): 714-22.

19. Olmez N, Degirmenci Y, Kececi H. Effects of pain and disability on QOL. Neuroscience \& Medicine. 2015: 6: 98-106.

20. Chiles NS, Phillips CL, Volpato S, Bandinelli S, Ferrucci L, Guralnik JM, et al. Diabetes, peripheral neuropathy, and lower extremity function. Journal of Diabetes and Its Complications. 2014; 28(1): 91-5. 